\title{
Legal Aid in Bangladesh: An Overview
}

\section{Mohammad Hasan Murad}

\author{
Associate Professor, Department of Law \\ International Islamic University Chittagong \\ Email:muradhs@yahoo.com
}

\section{Md. Sarowar Hossain}

Lawyer, Chittagong Judges' Court, Chittagong

\section{Doi:10.5901/jesr.2014.v4n3p279}

\begin{abstract}
Legal aid is a mechanism of providing assistance to people litigants and justice seekers who are otherwise unable to afford legal representation and access to the court system. Our poor litigant people cannot meet the expenses of the high fees of lawyers , as a result, they silently bear the of agonies and burns of injustice done to them in various spheres of life without any legal relief. This is nothing but a negation to them of one of their fundamental rights of equality before law and the equal protection of law. Legal aid is relatively a new phenomenon in Bangladesh compared to the centuries of old legal system in the country. In this article we have initially discussed the constitutional basis of Legal Aid in Bangladesh followed by an analysis of current legal provisions relating to state sponsored delivery models of legal aid in Bangladesh. We also presented a data sheet representing disposed and pending cases dealt by the District Legal Aid Committee of Chittagong.
\end{abstract}

\section{Introduction}

The Constitution of Bangladesh has in clear terms recognized the basic fundamental human rights. One of the basic fundamental rights is that all are equal before law and are entitled to equal protection of law (Article 27 of the Constitution of the People's Republic of Bangladesh). Article 14 of the said constitution stipulates that it shall be the fundamental responsibility of the state to emancipate backward sections of the people from all forms of exploitation; Article 31(2) guarantees protection of law that the citizens and the residents of Bangladesh have the inalienable right to be treated in accordance with law; Article 35(3) ensures speedy and fair triali. A range of international documents have also been framed for the safeguard of these rights. Articles 7, 8 and 10 of the Universal Declaration of Human Rights1948ii, Article 14 of the International Covenant on Civil and Political Rights 1966iii, Articles 6 (1) and 20 (1) of the Commonwealth of Independent States Convention on Human Rights and Fundamental Freedoms1995iv. Article 9 of the Arab Charter on Human Rights 1994v, Article 3 of the African Charter on Human and People Rights 1981vi, Article 24 of the American Convention on Human Rights 1978vii. The Legal aid helps with the costs of legal advice for people who cannot afford it. If anyone needs help with the costs of legal advice, he can apply for legal aid. Whether he will receive it depends on: the type of legal problem he has; his income (how much he earn) and how much capital (money, property, belongings) he has; whether there is a reasonable chance of winning his case and whether it is worth the time and money needed to win.

\section{Provisions of the Legal Aid Act, 2000 in Bangladesh}

Section 3 of The Legal Aid Services Act 2000 for an organization named National Legal Aid Organization which will organize and monitor proper functioning of this Act. Section 5 provides that the management and administration of the National Legal Aid Organization will be vested on a National Management Board the main function of which is to provide legal aid to poor litigants and to supervise the activities and effectiveness of the District Committeeviii. The main operating bodies are the district committees whose main function is to provide legal aid to poor litigants according to the rules and principles fixed by the National Legal Aid Organization and to adopt and implement projects and plans relating to legal aid in the district. Under the Act and rules framed there under a litigant can get legal aid on fulfillment of the condition of "financially incapable and poor". Who is financially incapable and poor? The rule specifies that it means a person whose 
yearly average income is not more than Tk $4000.00^{\text {ix }}$ An application for legal aid is to be submitted to the Board or the District Committee. If the application is made for legal aid for any matter in the Supreme Court, it is to be made to the Chairman of the National Legal Aid Organisation, i.e. the Minister of the Law, Justice and Parliamentary Affairs.

\section{The Legal Aid Services Act 2000( Aingoto Shohaiota Prodan Ain2000)}

The Legal Aid Services Act 2000 (Act VI of 2000) was enacted to help facilitating access to justice for poor people. The law provides for giving legal aid to poor people to institute or defend cases in courts. Legal Aid Committees headed by the respective District Judges have been constituted with government officer, lawyer and representatives from voluntary and woman organizations in each district. A statutory body called National Legal Aid Organization has been established and there is a national board of directors consisting of 19 members. This body is headed by the minister of the Ministry of Law, Justice and Parliamentary Affairs as chairman. The board also has the authority to consider application already rejected by the District Legal Aid Committee

\section{Who are eligible for legal aid in Bangladesh?}

The Act categorises the following groups of people as eligible to apply for the legal aid to the National Legal Aid Board and District Legal Aid Committees:

1. People with a certain minimum average income.

2. Physically disabled, jobless people, and freedom fighters whose Annual income is less than certain amount.

3. Recipients of retirement benefit.

4. Impoverished mothers holding VGD cards.

5. Women and children that are victims of acid burns, trafficking.

6. People having land or house at Adarsha Gram.

7. Financially insolvent widows economically disadvantaged women, deserted wives.

8. The handicapped that is helpless and incapable of earning.

9. Under trial prisoners that are unable to afford legal representation.

10. Persons declared insolvent or helpless by the jail authority.

11. Persons considered eligible for legal aid by the institution due to their insolvency, helplessness or socio economic backwardness ${ }^{\mathrm{x}}$

\section{Formation of National Legal Aid Board}

Formation of National Legal Aid Board has been described in the Section 6 of The Legal Aid Services Act 2000 ( Aingoto Shohaiota Prodan Ain2000) by 19 members.. While Minister of Law Justice And Parliamentary Affairs is the chair of the committee, 2 MP's from government and opposite party and other 16 members form government officials and other actors of justice work as members. The chair could nominate a member from voluntary organization. Nominated members function for 2 years providing that their nomination remains valid for the period. ${ }^{\mathrm{x}}$

\section{District Legal Aid Committee (DLAC)}

Formation of District Legal Aid Committee (DLAC) has been described in the Section 9 of The Legal Aid Services Act 2000 by 21 members. While District Judge is the chair of the committee, government officials and other actors of justice work as members. The chair could nominate a member from voluntary organization. Nominated members function for 2 years providing that their nomination remains valid for the period.

\section{Legal Aid Fund Collection}

Sources of funds and operation procedure of the fund have been described in Section 14 of the act. District Legal Aid Committee could accept contribution from both the person and the organizationxii. Chair (District Judge) and Secretary (Secretary of the District Bar Association) jointly operate the bank account of District Legal Aid Fund as enshrined in the act. Apart from the government fund, there are also separate funds managed by different non-government legal aid service providersxiii 


\section{Formation of Upazila and Union Committee}

Recently NLASO published gazette notification to form Upazila and Union legal aid committee under section 12 of Legal Aid Services Act 2000. xiv In the DLAC Chittagong has 14 Upazila and 11 Thana Committee and 193 Union Committee.xv

\section{Recent development of Legal Aid in Bangladesh}

Government legal aid program in the country for the last two years got more effective turn and seem to be functional. Considering pilot program success Government has decided in principle to amend the RTI Rules 2001 and Regulation 2001 which includes:

\subsection{Increasing lawyer fee:}

It was one of the common criticisms from lawyer's community that the lawyer fee is very poor in legal aid cases. Considering the situation lawyers fee has been increased. For preparing petition of civil and family matters lawyers fee has been proposed as tk.1500, at present it is 1200 . For preparing written statement of civil and family matters lawyers fee has been proposed as tk. 1500, at present it is 1200. Again, for preparing petition of criminal matters fee of assistant public prosecutor has been agreed to taka 800. For preparing admission and revision of application fee has been decided to be fixed as taka $400 \times v i$.

\subsection{Increasing eligibility range of 'insolvent person':}

Considering living standard of common people a gazette was published in 2009 where yearly income eligibility range has been increased to 30000 from 3000 . Recently Government has decided in principle that people whose yearly income does not exceed Tk.50000 are entitled to get help from this fund. Shortly gazette will be publishedxvii.

\subsection{Increasing eligibility range of Freedom fighters:}

Freedom fighter whose yearly income is within taka 75000 is entitled to get help from this fundxviii.

\section{Introducing district legal aid offices:}

Govt. has agreed in principle to set up District legal Aid Offices in 64 districts. Judicial officer whose rank is similar to assistant Judge will be designated as District legal Aid Officer. Office assistant and MLSS will be recruited also and some equipment like computer and photocopier will be provided for the District legal aid office. ${ }^{\text {ix }}$

\section{Yearly Case report of DLAC Chittagongxx}

\begin{tabular}{|c|c|c|c|c|c|c|c|c|c|c|c|c|c|c|c|c|c|c|}
\hline \multirow{3}{*}{$\begin{array}{l}\text { Year } \\
\text { of the } \\
\text { Report }\end{array}$} & \multicolumn{6}{|c|}{ Civil Case } & \multicolumn{6}{|c|}{ Family Case } & \multicolumn{6}{|c|}{ Criminal Case } \\
\hline & \multicolumn{3}{|c|}{ Application } & \multicolumn{3}{|c|}{ Disposal } & \multicolumn{3}{|c|}{ Application } & \multicolumn{3}{|c|}{ Disposal } & \multicolumn{3}{|c|}{ Application } & \multicolumn{3}{|c|}{ Disposal } \\
\hline & $\mathrm{M}$ & $\mathrm{F}$ & Total & $\mathrm{M}$ & $\mathrm{F}$ & Total & $\mathrm{M}$ & $\mathrm{F}$ & Total & $\mathrm{M}$ & $\mathrm{F}$ & Total & $M$ & $\mathrm{~F}$ & Total & $M$ & $\mathrm{~F}$ & Total \\
\hline 2001 to 2009 & & & 90 & & & 42 & & & 87 & & & 18 & & & 3011 & & & 2796 \\
\hline 2010 & 4 & 2 & 6 & 4 & 2 & 6 & 2 & 17 & 19 & 2 & 10 & 12 & 280 & 42 & 322 & 51 & 12 & 63 \\
\hline 2011 & 14 & 1 & 15 & 12 & 2 & 14 & 2 & 29 & 31 & 6 & 63 & 69 & 294 & 57 & 351 & 232 & 51 & 283 \\
\hline Total & 18 & 3 & 21 & 16 & 4 & 20 & 4 & 46 & 50 & 50 & 100 & 81 & 81 & 162 & 673 & 673 & 1346 & 346 \\
\hline
\end{tabular}

\section{Pending case in DLAC Chittagongxxi}

\begin{tabular}{|c|c|c|c|c|c|c|c|}
\hline \multirow{2}{*}{$\begin{array}{c}\text { Year } \\
\text { of the } \\
\text { Report }\end{array}$} & \multicolumn{5}{|c|}{ Total Case } & \multirow{2}{*}{ Case Pending } \\
\cline { 2 - 7 } & \multicolumn{3}{|c|}{ Application } & \multicolumn{2}{c|}{ Disposal } & \\
\cline { 2 - 7 } & $\mathrm{M}$ & $\mathrm{F}$ & Total & $\mathrm{M}$ & $\mathrm{F}$ & Total & \\
\hline 2001 to 2009 & & & 3188 & & & 2856 & 332 \\
\hline 2010 & 286 & 61 & 347 & 57 & 24 & 81 & 266 \\
\hline 2011 & 310 & 87 & 397 & 250 & 116 & 366 & 31 \\
\hline Total & $\mathbf{5 9 6}$ & $\mathbf{1 4 8}$ & $\mathbf{7 4 4}$ & $\mathbf{3 0 7}$ & 140 & $\mathbf{4 4 7}$ & $\mathbf{6 2 9}$ \\
\hline
\end{tabular}




\section{Conclusion}

Implementation of legal aid act in both developed and underdeveloped countries indicates government's willingness to serve the poor. Bangladesh is a developing country with more than thirty percent ultra poor population living in the darkness of illiteracy and therefore without access to any such state-run programme. The existing wide range of disparities between the poor and the rich can only be mitigated through strengthening this Legal Aid Programme which is closely linked with the Poverty Reduction Strategy and it must be seen as an instrument of achieving Millennium Development Goal. However, the government must also ensure that the act is regularly reviewed to address loopholes. The Government should follow a strategy of continuous improvement. In order to judge the success of reforms in legal aid provision, it is necessary to first establish a set of criteria against which it will be evaluated.

\section{References}

Constitution of the Peoples Republic of Bangladesh

Universal Declaration of Human Rights1948

The International Covenant on Civil and Political Rights 1966

The Commonwealth of Independent States Convention on Human Rights and Fundamental Freedoms1995

The Arab Charter on Human Rights 1994

The African Charter on Human and People Rights 1981

The American Convention on Human Rights 1978

The Legal Aid Services Act 2000

Providan 2001(Ammenment-2011).

The Legal Aid Policy 2001

The Legal Aid Services Act 2000

The End

The Legal Aid Services Act 2000

The Legal Aid Services Act 2000

District Legal Aid Committee, Chittagong,Report-2011-2-12

The Regulation 2001(Ammnent2011)

The Legal Aid Policy 2001

Regulation 2001(Amendment -2011)

District Legal Aid Committee, Chittagong,Report-2011-2-12

Md. Ershadul Islam, DLAC office Staff, Chittagong, Yearly Report 2011-2012.

Md. Ershadul Islam, DLAC office Staff, Chittagong, Yearly Report 2011-2012. 